\title{
RESUSCITATING THE AFRICAN GIANT: URBAN REGENERATION AND INNER CITY REDEVELOPMENT INITIATIVES ALONG THE 'CORRIDORS OF FREEDOM' IN DOWNTOWN JOHANNESBURG
}

\author{
Nico Kotze (D) • Leani de Vries \\ Department of Geography \\ University of South Africa \\ Florida Campus, Unisa, Private Bag X90, Florida, 1710: South Africa \\ e-mails: kotzenj@unisa.ac.za・dvriel@unisa.ac.za
}

\begin{abstract}
After more than two decades of attempting to redevelop the inner city of Johannesburg, it is still perceived by scholars, the popular media and the general public as a crime-ridden area of decay. This paper looks at a public transport system, as well as the redevelopment of parks and the provision of housing in the inner city. The Rea Vaya BRT serves as the 'backbone' for the redevelopment strategy of the City of Johannesburg's 'Corridors of Freedom' which aims to mitigate inequality in the city. This research analyses the success and shortcomings of the BRT system, as well as the redevelopment of inner city parks and the provision of housing for the poor in the inner city and along these development axes. Although large amounts of money have been allocated to the redevelopment of the inner city parks and to tracts of land along these so-called Corridors of Freedom, these parks are still proving to be user-unfriendly owing to a lack of maintenance. Although the redevelopment projects appear to be worthy attempts to improve the inner city of Johannesburg these have as yet not proved themselves to be very effective.
\end{abstract}

\section{Key words}

Johannesburg $\bullet$ urban regeneration $\cdot$ redevelopment $\cdot$ parks $\cdot$ housing $\bullet$ transport

\section{Introduction}

The 'White flight' from the inner city, as well as the institutional disinvestment of capital from the central business district, has contributed towards the physical decline of many of these areas in most of the South African cities (Beavon 2005; McDonald 2008). This same process was observed in Johannesburg during the 1970s and 1980s, subsequent to the flight of white inner-city residents and businesses to Randburg, Sandton, Rosebank, as well as Midrand, further towards the north, with the result that the inner city 
started to decline (Young 2012; De Vries \& Kotze 2016). In pursuit of urban regeneration in South Africa, a range of urban renewal programmes was introduced over decades in an attempt to solve this problem. The urban programmes in this country, as well as globally, have been driven by urban planners, private developers, and government bodies (Turok \& Mykhnenk 2007; Visser \& Kotze 2008).

Generally, the process of globalisation has homogenised cities of the world and it is only the local traditions and cultural heritage of the individual countries that have allowed for these urban changes to be distinguished, one from the other, in the respective cities (Boussaa 2018).

Economic, physical environmental and socio-cultural (community redevelopment) factors have played an important role in the analysis of urban dynamics and change in cities, and importantly, it is a combination of the afore-mentioned variables that has served to eventually produce the land-use changes that are so obviously evident within the cities of today (Trósányi 2011; Jones \& Evans 2013).

According to Couch, Sykes and Börstinghaus (2011), urban regeneration/renewal is a term that is used to define the process of slum clearance and the physical redevelopment of an urban area. This is a process that has become one of the main strategies in the built environment to promote and accommodate change, as well as economic growth (Trósányi 2011; Jones \& Evans 2013), and that found reverberation in North America in the mid-20th century, but also in British and European cities (Couch et al. 2011; Nikšič et al. 2018).

Land-use in cities is constantly changing, with the result that urban redevelopment projects and planning initiatives in the built environment of these urban areas is commonplace (Boussaa 2018). Urban regeneration projects are generally initiated with the intention of changing downgraded and derelict areas in the city centre or deserted industrial areas into desirable urban spaces (Güzey 2009). There was an intensive movement in this direction after the Second World War in Europe and Britain owing to the decline of industry. It was driven by the necessity of reconstructing degraded urban districts, because the older cities could not cope with the new challenges facing them (Trósányi 2011; McDonald et al. 2009). These changes did not only apply to abandoned industrial areas but also included large housing estates that accommodated the work forces for these industries (Nikšič et al. 2018).

One of the more recent attempts at urban regeneration in Europe is the new focus of urban planners on Human Cities. In fact, these projects have been running since 2014, and to date (2018) eleven cities have been subjected to the Creative Europe programme (Human Cities n.d.). The objective of this programme is to test new approaches by experimenting with public participation programmes related to urban regeneration in public spaces (Nikšič et al. 2018).

In the case of South Africa, according to Visser and Kotze (2008), one of the more recent developments in the management of inner-city redevelopment projects in the country has been the introduction of centralcity improvement districts (CCIDs), especially in Cape Town and Johannesburg (also see Lemanski 2007; Pirie 2007). However, the process was severely hampered during the late 1990s when the City Council of Johannesburg was faced with technical bankruptcy and the administrative powers of the council were rescinded under exceptional circumstances when the national and provincial governments of South Africa intervened (City of Johannesburg 2001; Beall et al. 2002; Lipietz 2008). Owing to the financial problems that the City of Johannesburg was facing towards the end of the 20th century, it was slow to respond to the challenges of a decaying $\mathrm{CBD}$ and of the fragmented structure of the city.

According to Chapman (2015), South Africa has already entered its third decade of democratic governance and most of the state-funded urban design projects have aimed at re-uniting Johannesburg. In fact, 
these same processes are also being duplicated in other cities in the country. According to scholars such as Winkler (2013) and Schnehage (2012), more than two decades have passed since the public sector put plans in place to regenerate the inner city of Johannesburg and yet there are still only isolated pockets of regeneration in areas within the CBD, while suburbs such as Hillbrow are still perceived as derelict slums. It will take much longer for the more affluent residents to return to the CBD (as cited by Winkler 2013). Although much planning has taken place since 1994, and policies have been developed, the application of plans for the Corridors of Freedom, driven by the City of Johannesburg for uniting the city, is a more recent initiative (Chapman 2015).

Although volumes have been published on the decline of Downtown Johannesburg, and numerous reports have been published on urban regeneration projects launched within this inner city area, these studies have merely looked at specific problems within this central part of the city. This paper, on the other hand, is based on a number of different urban renewal studies conducted by the authors in the CBD area of the city and is an attempt at explaining why this part of the city still seems to be on a downward spiral of decay, notwithstanding the large amounts of money that have been allocated towards effecting improvements in the CBD of one of the largest cities in Africa.

This paper is divided into six sections. The first is the introduction to urban decline and renewal in Johannesburg; the second is the literature review, which looks at the 'Corridors of Freedom' project embarked upon by the City of Johannesburg to bring about a reversal in the decline and the current image of disorder, neglect and the filth of the city. Furthermore, it looks at increasing connectivity between and access to the different areas of the city, and at opportunities along the various transport routes. The third section covers the renewal of the inner-city transport system, while the fourth presents a discussion on the development of housing for the poor in abandoned buildings in the CBD and along the 'Corridors of Freedom'. The fifth section showcases the attempts to create improved inner city parks and open spaces for the growing number of downtown inhabitants. The final section offers recommendations and concluding remarks.

\section{Downtown Johannesburg and the 'Corridors of Freedom'}

The African giant, Johannesburg, best known to locals as 'Joburg', has undergone a process of urban decline over five decades ever since the 1970s, on account of the flight of white businesses and residents from the inner city to the more attractive northern metropolitan areas of Midrand, Sandton and Randburg (Young 2012) (see Fig. 1 for these locations). In an attempt to give the city new life and to eradicate the social, spatial and economic imbalances of the past, the City of Johannesburg is embarking upon its latest spatial vision, the so-called 'Corridors of Freedom' project, which aims to 're-stitch' the city in pursuit of creating a 'new future' for its urban residents (City of Johannesburg n.d.[a]). This type of 'broader, city-wide' infrastructural development has the potential to beneficially impact upon economic growth and development within the country, as well as upon the city itself and could contribute to the alleviation of poverty and towards a sustainable environment (SACN 2014). These public works programmes of the country are also being used to good effect to alleviate poverty and create employment (Thwala 2008).

The implementation of the Corridors of Freedom concept was initiated during 2012 by the City of Johannesburg (CoJ) in collaboration with the Johannesburg Development Agency (JDA). This vision coincides with a unique change in approach from elevated planning to one with greater focus being directed towards implementation. This involves the intensification of programmes and projects by the city for upgrading the public space and the social infrastructure 
which were initially designed to take place within a year and were made possible through improved national and local monetary policies (Chapman 2015).

In essence, the Corridors of Freedom is a form of transit-oriented development (TOD) that incorporates transport routes and nodes around which mixed-use developments are concentrated. These corridors allow the residents to stay, work and play within their confines without having to deal with the problem of vast distances separating them from the facilities and spaces that the residents would want to use (City of Johannesburg n.d.[a]).

There are currently three priority corridors that extend outward from the inner city and include the Empire-Perth (southwest), Louis Botha Avenue (northeast) and Turffontein (south) Development Corridors. Within the corridors, provision has been made specifically for high-density accommodation and housing, leisure and recreational facilities, office and retail developments, and an established transport network, which forms the 'backbone' and links the different forms of land-use (City of Johannesburg n.d.[a]).

Besides encouraging inclusivity and access to the city's resources, the Corridors of Freedom project also aims to contribute towards the sustainable future of Johannesburg, in which a limited carbon footprint is envisaged (City of Johannesburg n.d.[a]). The concept of the Corridors of Freedom was outlined in the 2012/16 Integrated Development Plan (IDP) for the city and was first made known in 2013/14 as part of the City's Growth and Development Strategy (City of Johannesburg 2015). The guidelines for the development of each corridor are set out in the Strategic Area Framework (City of Johannesburg n.d. [b]; City of Johannesburg n.d. [c]; City of Johannesburg n.d. [d]).

Overall, inner city redevelopment initiatives have been spearheaded particularly by the public-private entity, the Johannesburg Development Agency (JDA), which was established in 2001 and has been responsible for the bulk of public investment in Downtown Johannesburg (Bethlehem 2013). Amongst others, the JDA saw the stunning Nelson Mandela Bridge and Newtown developments come to life, while it has also been responsible for various public space and infrastructural upgrades in the form of inner-city parks and the Rea Vaya Bus Rapid Transit System (Bethlehem 2013).

The various strategies and plans of the City ultimately feed into the broader Johannesburg 2040 Strategy that envisions Johannesburg as: "[...] a World Class African City of the Future - a vibrant, equitable African city, strengthened through its diversity; a city that provides real quality of life; a city that provides sustainability for all its citizens; a resilient and adaptive society. Joburg. My City Our Future!" (City of Johannesburg 2013: 51).

In this article, the three pillars that are critical to the urban renewal of Johannesburg will be discussed. The article will also unpack how these and related developments are integrated as part of or complementary to the Corridors of Freedom project. It will also look into the provisions that have been made by the city, and how successful the implementation of these initiatives has in fact been.

\section{Rea Vaya: the 'backbone' of the Corridors of Freedom project}

Transport forms a key component in all of the urban renewal projects of the City of Johannesburg and is also described as the 'backbone' of the Corridors of Freedom project in that it connects the spaces where people stay, work and play. In developing Johannesburg's transport network and thus the mobility of its residents, the City is pursuing what is called transit-oriented development and non-motorised transport (NMT) (City of Johannesburg 2015). The development of the Rea Vaya Bus Rapid Transit (BRT) system will also help to mitigate the discrimination experienced by certain sectors of society emanating from the inherently and structurally unequal society of the past, by providing transport mobility to the underprivileged. This will serve to diminish inequality between the residents of the city (Coggin 2015). 
The Rea Vaya BRT system specifically forms the 'backbone' of the Corridors project and connects mixed-use developments. Concomitantly, the cycling and pedestrian infrastructure of the city is also being developed and upgraded. The intention of the City of Johannesburg is also to bring about mode integration whereby the Rea Vaya and NMT network will connect with the Gautrain, Metrobus, PRASA rail, and minibus taxi services.

As part of the City of Johannesburg's 'Corridors of Freedom' redevelopment initiative, the Rea Vaya BRT system was launched in August 2009 for the staging of the Soccer World Cup, hosted by South Africa in 2010 (Lockhat \& Kotze 2017). Initially, it connected Soweto, the poorer southern townships, with the central city by means of three trunk routes. The city is currently developing new bus routes to the underdeveloped township of Alexandra, in the north-east, and linking them via walkways and bridges to bus routes to Sandton, to the north of the CBD, and also to the CBD itself (see Fig. 1).

The Rea Vaya bus scheme is the longest functional BRT system in South Africa and is aimed at transforming the ailing public transport sector in the country (Barrette 2003; Pirie 2013). Over the past two decades, the government has invested heavily in BRT systems in most of the major cities owing to its failure to regulate the dominating mini bus taxi industry in the country (Walters 2013).

The Rea Vaya BRT system caters for traffic-engineered, dedicated bus lanes with traffic signals that provide for the right of way for buses at intersections. Bus stations have been developed along the major routes, providing protection for the passengers, and ease of access, with platforms level to the boarding points of the buses (Kotze 2015; Lochat \& Kotze 2017).

A passenger information system was included in the design of the BRT system

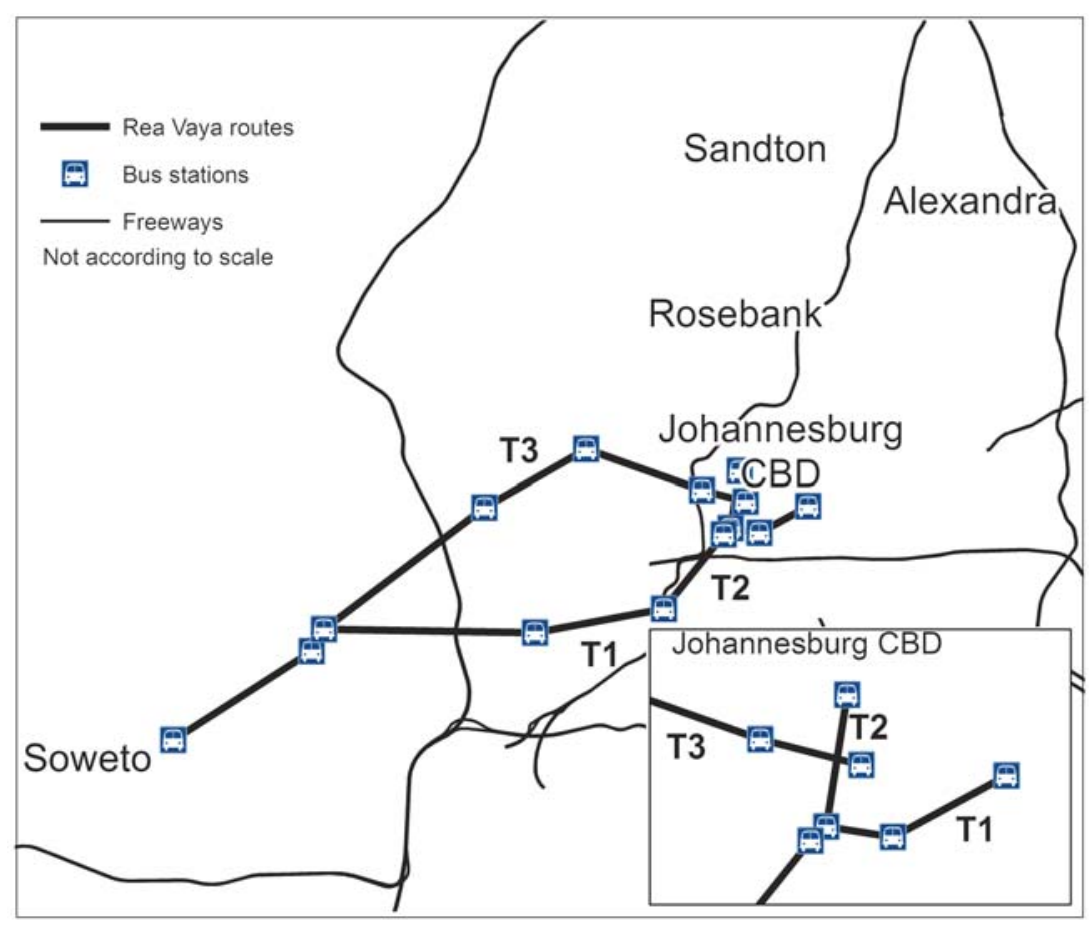

Figure 1. A schematic map of the Rea Vaya trunk routs 
in the form of live digital information screens showing the arrival times of the buses. Furthermore, the Rea Vaya webpage indicates that buses should run every 10 minutes during peak hours (Lochat \& Kotze 2017).

As with the fare collection in most BRT systems, it is off-board to reduce the time spent in boarding the buses, with two payment options available, namely single/return tickets that are approximately 50\% more expensive than the smart cards that can be preloaded with funds and used to tap in and out of the bus stations (Kotze 2015; Lochat \& Kotze 2017).

Although it seems that the Rea Vaya BRT system can compete with the best in the world, the system is gradually failing the commuting public of the city. In their study during 2015, Lockhat and Kotze (2017) found that less than $15 \%$ of the buses were running on time. Since this study, it seems that the arrival times of buses at bus stops are even more erratic, resulting in total overcrowding by commuters at bus stops and in buses on particular routes during the peak hours (Lochat \& Kotze 2017).

From the start of this operation, the digital information screens proved to be very inaccurate and during 2017 totally inoperative at all stations, leaving passengers with no idea of the arrival time of the next bus. Furthermore, from an observer's perspective, the condition of the buses seems to be deteriorating with dilapidated doors that do not open properly or not at all, and with battle-scarred bodywork resulting from the collisions of the buses with objects on their daily routes (Kotze 2015; Lochat \& Kotze 2017).

A further problem that is of increasing concern is that the bus stations are frequently off-line, resulting in commuters being unable to reload their smart cards with funds. They are then forced to buy the much more expensive single/return bus tickets. On the other hand, if an entire station at the end destination of a journey is off-line, the passenger is unable to validate his/her trip, which results in a penalty if not done within a 24-hour period (Moageng \& Goondiwala 2015).
Most of the problems associated with Rea Vaya can be resolved with an improved organisational structure, by incorporating adaptations learnt from observations of the MyCiti BRT system of Cape Town, a system that seems to have been totally embraced by the commuters of the city. Because the City of Cape Town took the wise step of appointing multiple bus operators, as well as a number of bus station companies, healthy competition has been assured among the service providers that can only result in a better functioning service for commuters. To solve the problem of the unreliability of the Rea Vaya buses, the CCTV cameras installed at most of the bus stops should be repositioned to ensure security at the bus stops, and also to monitor the arrival times of the buses.

Currently, only one bus operating company is used by the City of Johannesburg (Lochat \& Kotze 2017). By contracting more bus operating companies, competition can be created between the competing companies to ensure a reliable service to commuters. Underperforming bus operating companies can be penalised by reducing the number of routes or the distances covered by the buses in their contracts with the City of Johannesburg. The same could be achieved with the bus stations. By establishing contracts with competing companies, a more reliable and an improved service could be afforded to the commuters using Rea Vaya.

Finally, the maintenance of the buses could be improved by withdrawing a bus from service one day per week to sort out the mechanical and bodywork problems of the vehicles. Again, this aspect is also featured in the model used by the MyCiti buses in Cape Town, resulting in a seemingly better-maintained fleet of buses.

\section{Housing the poor in the inner city and along the Corridors of Freedom}

According to the South African Constitution, Sections 26 (1) and (2), every citizen has the right of access to adequate housing (COHRE 
2005). Because of this stipulation in the constitution, the ANC-led government has promised the delivery of affordable accommodation to the poor since 1994 (Zack et al. 2010). According to Poulsen (2010), there are several government-supported housing institutions, such as the Johannesburg Social Housing Company (Joshco), that have been structured to provide housing for the poor, who are unable to pay for housing in the main-stream rental market.

However, housing policies in the past, especially during the Apartheid era, led to restrictions that severely limited the supply of available and affordable rental housing for the urban poor in South Africa (Matjomane 2012). Because of this, Johannesburg, has been faced with a housing crisis ${ }^{1}$. At the same time, there has been a large demand for low-income rental housing in the inner city of Johannesburg specifically, as well as in all the major urban centres of the country (Tissington 2013).

As a consequence of over-investment in commercial buildings in the inner city of Johannesburg in the past, and the collapse of the influx controls in 1986, the innercity population of Johannesburg started increasing, and with it, the 'greying' of its neighbourhoods took place. These trends resulted in a decline in investor confidence and in the property values of the inner-city areas of Johannesburg, so that many of the residential and commercial property owners abandoned their buildings.

These changes in the fabric of the CBD of the city resulted in increasing numbers of squatters invading these abandoned buildings. Because the City of Johannesburg did not enforce the building standards and regulations, as well as the local health and safety by-laws, the number of 'bad' buildings started to increase within the inner city (COHRE 2005; Zack et al. 2010). These derelict buildings are generally over-crowded, unsafe and violate most of the local government by-laws

1 The backlog is more than 2.4 million housing units nationally (Ross et al. 2010; Mayson \& Charlton 2015) and are perceived as an embarrassment to and as unwanted by most cities (Wilson 2014).

In Johannesburg, there is a mismatch between well-located low-income housing and the demand for this type of accommodation. Furthermore, the demand for such housing is totally outstripping the supply (Tissington 2013; Lembede 2016). Additionally, it is only as a result of substantial subsidisation by the government/metropolitan council and external support by the private sector and NGO's in an attempt to provide housing for the poor, that these low-cost housing developments within the inner city can be continued ${ }^{2}$ (COHRE 2005)

Thus, because of the shortfalls in delivering adequate and affordable housing to low-income population groups by the private sector and social housing agencies, the poorer inhabitants of the inner city of Johannesburg are forced to find alternative types of housing that do not conform to societal standards. This the residents do by renting sub-divided properties and houses, unlawfully occupying dilapidated commercial buildings, renting illegally subdivided apartments, and by doing this, rooms or parts of rooms, or even balconies, as well as backyard dwellings. These activities provide accommodation for the poor closer to work opportunities within the CBD of Johannesburg (Tissington 2013; Lembede 2016). Although the majority of these categories of informal housing typologies in the city can be viewed as slumlike structures, they do provide alternative accommodation opportunities for lowincome earners, and are in greater demand than in the case of those informal housing typologies on the periphery of Johannesburg (Lembede 2016).

Furthermore, the inner city of Johannesburg is an area with a large number of poorly

\footnotetext{
2 The development of housing in the inner city of Johannesburg should also be seen as a form of gentrification that is taking place, because the poor, who have been occupying these apartments, are now being replaced by more affluent tenants (see Visser \& Kotze 2008; Kotze 2013)
} 
maintained buildings that do not comply with the prerequisites of the municipal by-laws. These buildings are structurally hazardous with insufficient fire prevention equipment and inadequate sanitation and other facilities. However, people are living in these unacceptable structures which could prove to be hazardous to their lives and health (COHRE 2005).

The City of Johannesburg views these derelict buildings as more than unhealthy and unsafe; in fact, as sinkholes of criminal activities that have a deleterious effect on public space and that defeat the purpose of renewal projects for upgrading the CBD of the city. These buildings are sold off for commercial redevelopment by the council, while others are redeveloped under the 'Better Building Programme' to provide low-cost housing in the city. However, this process results in rentals that are well above the means of the prospective poor buyers and that are incurred long after the original occupants have been evicted from these buildings (COHRE 2005).

To guard against gentrification, the redevelopment activities in city centres need to be oriented in favour of the poor; alternatively, specific regulations and policies must be put in place. Otherwise, the poor will be driven out of these areas as the afore-mentioned become more sought-after, resulting in an increase in property prices and rentals (Harrison 2006).

\section{Parks, leisure and recreational opportunities along the Corridors of Freedom}

Johannesburg's parks and open spaces form one of several of the priority areas in urban renewal projects and the redevelopment programmes of the city. The CSIR recommends an open space provision of $0.5 \mathrm{ha}$ per 1000 of the population in urban areas (CSIR 2012). While Johannesburg contains the second-largest number of green spaces of the 15 cities evaluated in the African Green City Index, and boasts an estimated
$231 \mathrm{~m}^{2}$ of green space per person which is roughly three times the average for African cities, the parks and open spaces, in the inner city of Johannesburg particularly, are still in a poor condition and lacking in facilities and in the provision of effective management and efficient maintenance services (Economist Intelligence Unit 2011).

There are over 2000 parks and open spaces in Johannesburg alone. Provision for these parks and redevelopment operations are adequately catered for and incorporated in the City's Integrated Development Plans and Spatial Development Frameworks. While Johannesburg's Department of City Parks and Zoo represents the key steward of these parks and is responsible for both their maintenance and development, the JDA has continued to partner with the City and play a pivotal role in the re-developmental initiatives for the parks and public environments of Johannesburg.

While downtown parks and open spaces are adequately incorporated into the broader strategies and renewal plans of the City, several factors have proven challenging and constraining to their successful management and maintenance once the upgrades have taken place. This is especially due to the fact that the social, economic and spatial dynamics pose a completely unique challenge as to the manner in which parks and open spaces are typically maintained in other areas of Johannesburg. A rapidly growing population is dramatically increasing the pressure on and the demand for inner city amenities, that are already suffering as a result of limited budgets for their maintenance and their state of good repair and cleanliness.

Valuable lessons can be drawn from the challenges of maintaining the inner city park developments for the new Corridors. Parks and open spaces, along with local shops, schools, clinics, and police stations are designated as important components of the 'social infrastructure' in the mixed-use Corridors of Freedom (City of Johannesburg 2015; City of Johannesburg n.d.[a]). Within the corridors specifically, City Parks is responsible for 
17 projects which will eventually amount to an expenditure of R125 million, while the JDA will undertake seven projects to upgrade the public environment at a cost of R152 million (City of Johannesburg n.d.[d]).

For example, within the Empire-Perth Corridor, that is directly linked to the inner city, limited provision is currently being made for quality open spaces in terms of accessibility, and furthermore, the prevailing conditions are not appealing to users. Most are situated outside of walking distance of the residential areas and are also in a very poor condition. The City, however, recognises that "good transit corridors and sufficient open spaces, which, ideally, are [located in close proximity to], or easily accessible to areas of high population density within the corridor", are essential (City of Johannesburg n.d.[b]: 44). The City also recommends that parks and open spaces within good transit corridors should be accessible in that they should form part of a connected network and be accessible through a mode of non-motorised or public transport (City of Johannesburg n.d.[c]).

In an assessment done by the City of Johannesburg, it was determined that the Empire-Perth Corridor has over 195 ha of public open space, which equates to $1.5 \mathrm{ha}$ per 1000 of the population in the Corridor (City of Johannesburg n.d.[b]). There are, however, a number of plans in place for upgrading and developing parks in the corridor, a few of which are tabled below (Tab. 1).

The Louis Botha Corridor, on the other hand, is better provisioned with a fairer distribution of 'social infrastructures', that include well-maintained parks (City of Johannesburg n.d.[c]). However, the City has identified and allocated a number of park upgrades, a few of which are tabled below (Tab. 2).

A public open space analysis was conducted of the Turffontein Corridor to assess the total area of open space, the quality of the environment, and the distance of the local population from the parks (City of Johannesburg n.d.[d]). It was determined that the corridor has at its disposal over 319 hectares for its total population of just under 82,000 . This equates to a provision of three hectares per 1000 of the population which is well over the CSIR's recommended guidelines. City Parks, however acknowledges that while the corridor can provide sufficient areas of open space, it lacks in the quality of the space in that the parks are neglected and the amenities are in a poor state of repair. Furthermore, they are also not often used for open space functions by the public and are generally inaccessible (City of Johannesburg n.d.[d]). The open spaces in this corridor consist mainly of natural ridges and veld, and are associated with issues of safety and illegal dumping (City of Johannesburg n.d.[d]). A few of the planned upgrades are tabled below (Tab. 3).

On account of their 'restorative potential', parks and open spaces play a critical role in reviving decaying cities (Thwaites et al. 2005). Parks and open spaces also serve an important function in responding to the social and recreational needs of the public in that they enhance the living and recreational environments of the local residents. Thus, the concept of Corridors of Freedom, which envisages the accommodation of urban dwellers in residential units close

Table 1. Park upgrades in the Empire/Perth Corridor (City of Johannesburg n.d.[b])

\begin{tabular}{|l|c|c|}
\hline \multicolumn{1}{|c|}{ Initiative } & Responsible Division & Budget Allocated \\
\hline New parks development in Empire/Perth Corridor of Freedom & City Parks and Zoo & $\mathrm{R} 13,500,000$ \\
Upgrading of existing parks in Brixton & City Parks and Zoo & $\mathrm{R} 3,000,000$ \\
Upgrading of Katjiepiering Street Park in Vrededorp & City Parks and Zoo & $\mathrm{R} 2,000,000$ \\
Westdene Dam Park development & City Parks and Zoo & $\mathrm{R} 21,970,000$ \\
Westbury Parks Upgrade & City Parks and Zoo & $\mathrm{R} 10,000,000$ \\
\hline
\end{tabular}


Table 2. Park upgrades in the Louis Botha Corridor (City of Johannesburg n.d.[c])

\begin{tabular}{|l|c|c|}
\hline \multicolumn{1}{|c|}{ Initiative } & Responsible Division & Budget Allocated \\
\hline Six new local parks & City Parks and Zoo & $\mathrm{R} 10,000,000$ \\
Yeoville Park upgrade & City Parks and Zoo & $\mathrm{R} 4,600,000$ \\
Pocket Places - small urban spaces within the Corridor & Johannesburg & $\mathrm{R} 15,660,000$ \\
& Development Agency & \\
Upgrading of Pieter Roos Park & City Parks and Zoo & $\mathrm{R} 1,500,000$ \\
\hline
\end{tabular}

Table 3. Park upgrades in the Turffontein Corridor (City of Johannesburg n.d.[d])

\begin{tabular}{|l|c|c|}
\hline \multicolumn{1}{|c|}{ Initiative } & Responsible Division & Budget Allocated \\
\hline Upgrading of Pioneer Park & City Parks and Zoo & $R 10,000,000$ \\
Establishment of parks within the Turffontein Corridor & City Parks and Zoo & $R 16,000,000$ \\
\hline
\end{tabular}

to their places of work and recreation (SACN 2014), relies heavily on the provision of parks and open spaces.

In a conversation with the Inner City Park Manager, responsible for Region F of Johannesburg, a few challenges came to light and would need to be addressed in order to ensure success in the City's current projects, including those of the corridors extending to other regions of the City:

The first challenge relates to the upkeep and maintenance of Johannesburg parks. These are classified as either flagship, developed or underdeveloped. One of the larger flagship parks is the inner city's historic Joubert Park, that dates back to the late 19th century. It is maintained on a more regular basis (Marais 2013) than the smaller community and local parks and open spaces in the area where the challenges of crime and population pressure make it difficult to keep to a set maintenance schedule.

A second challenge is the constraints that the City is experiencing in terms of time, budgetary and man-power limitations. The success of these initiatives would be dependent on an understanding of the needs of the communities residing in the vicinity of each respective park, the sense of place of the public to take responsibility in helping to take care of their parks, a greater allocation of resources, and more effective partnerships between the key role-players.

Considering the inadequacies that have been shown in providing for parks and open spaces in the inner city especially, the problematical nature of the parks and open spaces in terms of their level of maintenance, additional pressures in the form of over-utilisation and degradation must be assessed so that they can be planned for in greater detail. In so doing, the success of the City's latest projects, including the Corridors of Freedom, would be assured. The relevant role-players should also be equipped with adequate resources, more developed skills and be supported by more effective partnerships in order to maintain redevelopments and to reach the desired outcomes.

\section{Concluding remarks}

The deterioration and collapse of the CBD of Johannesburg is not a unique phenomenon to this city in particular since most of the central business districts of most of the larger urban centres in South Africa have suffered the same fate. Because Johannesburg is the economic hub of the country, the derelict state of the CBD seems to most observers to be more severe. Although large amounts of money have been poured into renovation projects 
and attempts to improve the CBD of the city, it appears that there are only small pockets of rejuvenated areas within the inner city.

Rea Vaya is the oldest BRT system in South Africa. It incorporates all the components of a well-engineered commuting system, ranging from designated runways for buses along trunk routes to vehicles and bus stations that provide for the needs of commuters. But because of problematical organisational shortfalls with bus scheduling and IT problems at the bus stops, the backbone of Johannesburg's 'Corridors of Freedom' that was envisaged for assisting the poor inhabitants of the city to commute between their homes and work is actually leaving them stranded.

The housing crisis in the downtown area of Johannesburg has played a major role in causing the collapse of the CBD of the city. Because of the lack of affordable housing available to the poor who would naturally seek accommodation close to their places of work, they are forced into unhealthy and unconventional over-crowded living conditions. They must resort to living in slum-like conditions and to occupying 'bad' buildings. This trend, which is prevalent in the city centre of Johannesburg, will be difficult to eradicate. Where the authorities do in fact manage to forcefully evict these illegal inhabitants and turn these buildings around, gentrification then starts to take a foothold with more affluent inhabitants moving in to this improved accommodation.

The attempts by the City of Johannesburg to regenerate the parks are not reaching their lofty goals of providing a welcoming area for the urbanites. The City Parks department finds it problematical to maintain these recreational areas. This is due to a lack of funds and perhaps also to an unruly urban population that causes funds to be constantly diverted to upgrade these parks as a result of vandalism to boundary fences, ablution and playground facilities.

The 'Corridors of Freedom' urban regeneration initiative of the City of Johannesburg seems to have very strong political and emotional undertones. The circumstances should be viewed in the light of the Apartheid era, which only started to unravel in 1986 when the Influx Control legislation was abandoned, and only came to a climax in 1994, when the ANC government came to power. The new local government tried to reunite a divided city by undoing the legacies of the past, with debatable success. However, similar to so many of the debatable initiatives by the public sector in South Africa, this renewal strategy for the City of Johannesburg also seems doomed to failure on account of the Rea Vaya BRT system, that forms the backbone of the Corridors of Freedom initiative and is currently failing the commuters. Furthermore, it can be seen to be strengthening the legacy of the past, by limiting the possibility of housing the poor black population only to the periphery of the city

The park redevelopment programme appears to be totally inadequate in providing for the needs of the inner city population. The renovation and redevelopment of buildings and the attempts to provide housing for the poor in the inner city of Johannesburg seem to have been only moderately successful, one of the reasons being that these endeavours could also be perceived as state-funded gentrification programmes.

Finally, although valiant attempts at urban regeneration projects have been launched since 1984 by the City of Johannesburg (CoJ) to improve the image of the inner city, it seems that the CoJ has not been successful. It is evident from these case studies of Johannesburg that lofty ideals alone will not improve the image and built environment of this large African city. What is also needed is the commitment of all role players, namely the citizens, private developers and most importantly the local authority to change Downtown Johannesburg into a "World Class African City of the Future".

\section{Editors' note:}

Unless otherwise stated, the sources of tables and figures are the authors', on the basis of their own research. 


\section{References}

Aigbavboa C.O., Thwala W.D., 2013. Housing satisfaction in subsidised housing schemes: a case study of Johannesburg, Gauteng Province, South Africa. Journal of Human Ecology, vol. 42, no. 3, pp. 245-257.

BARRET J., 2003. Organizing in the informal economy: A case study of the minibus taxi industry in South Africa. No. 993581583402676, International Labour Organization.

Beall J., Crankshaw O., Parnell S., 2002. United: A divided city: Governance and social exclusion in Johannesburg. London: Earthscan.

BEAvON K.S.O., 2005. Johannesburg: The making and shaping of the city. Pretoria: University of South Africa Press.

Bethlehem L., 2013. A new dynamic - urban regeneration in the Jo'burg CBD. The Journal of the Helen Suzman Foundation, vol. 69, pp. 17-24.

BousSAA D., 2018. Urban regeneration and the search for identity in historic cities. Sustainability, vol. 10, no. 48, www.mdpi.com/journal/sustainability [17 October 2018].

Chapman T.P., 2015. Spatial justice and the Western Areas of Johannesburg. African Studies, vol. 74, no. 1, pp. 76-97.

City of Johannesburg, n.d.[a]. Corridors of Freedom: re-stitching our City to create a new future. https://www.coursehero.com/file/16296618/ corridors-of-freedom-s/ [28 December 2018].

City of Johannesburg, n.d.[b]. Empire-Perth Development Corridor Strategic Area Framework. www.cidforum.co.za/files/EMPIRE_PERTH_ SAF_FINAL_DRAFT.pdf [25 November 2018].

City of Johannesburg, n.d.[c]. Louis Botha Avenue Development Corridor Strategic Area Framework. www.sajr.co.za/docs/default-source/ pdf/2016-pdf-docs/louis-botha-final-sajr. pdf?sfvrsn=2 [25 November 2018].

City of Johannesburg, n.d.[d]. Turffontein Development Corridor Strategic Area Framework. https://drive.google.com/drive/folders/0B2v6a bwVoMI3MGw3QmpIN1BkVGs [25 November 2018].

City OF JohAnNesburg, 2001. Johannesburg: an African city in change. Cape Town: Zebra Press.
City of Johannesburg, 2013. City of Johannesburg: 2012-2016 Integrated Development Plan: 2013/14 Review. https://joburg.org.za/ images/stories/2013/June/2013-16\%20idp\%20 17may2013\%20final.pdf [25 November 2018].

City of Johannesburg, 2015. 2012/2016 Integrated Development Plan: "Turning Challenges into Opportunities" 2015/2016 Review. https:// joburg.org.za/images/stories/2015/June/201516\%20IDP\%20Review.pdf. [25 November 2018].

CogGIN T., 2015. A right of transport? Moving towards a right-based approach to mobility in the city. South African Journal on Human Rights, vol. 31, no. 2, pp. 294-314.

COHRE, 2005. Any room for the poor? Forced evictions in Johannesburg, South Africa: Draft for discussion. Johannesburg: Centre on Housing Rights and Evictions.

Couch C., Sykes O., BöRstinghaus W., 2011. Thirty years of urban regeneration in Britain, Germany and France: The importance of context and path dependency. Progress in Planning, vol. 75, pp. 1-52.

CSIR, 2012. CSIR Guidelines for the provision of social facilities in South African settlements. Pretoria: Council for Scientific and Industrial Research.

De VRies L., KotZe N., 2016. The revitalisation of parks and open spaces in Downtown Johannesburg. Urbani Izziv, vol. 27, no. 1, pp. 123-131.

ECONOMIST INTELLIGENCE UnIt, 2011. African Green City Index: Assessing the environmental performance of Africa's major cities. Munich: Siemens AG.

GüZEY Ö., 2009. Urban regeneration and increased competitive power: Ankara in an era of globalization. Cities, vol. 26, no. 1, pp. 27-37.

HarRISON P., 2006. On the edge of reason: Planning an urban future in Africa. Urban Studies, vol. 43, no. 2, pp. 319-335.

Human Cities (n.d.), Challenging the city scale, 2014-2018. www.humancities.eu [20 October 2018].

JONes P., Evans J., 2013. Urban Regeneration in the UK. London: Sage.

Kotze N., 2013. A community in trouble? The impact of gentrification on the Bo-Kaap, Cape Town. Urbani Izziv, vol. 24, no. 2, pp. 124-132. 
Kotze N., 2015. Johannesburg's Rea Vaya bus rapid transit system: Perceptions and reality of service delivery [in:] S. Goodman, G. Human, C. Mulenga,D. Priilald, J. Robertson(eds.), Management in South Africa: Changes, challenge and opportunity, Proceedings of the 27th Conference of SAIMS - 2015, The South African Institute for Management Scientists, Cape Town, South Africa.

LEMANSKI C., 2007. Global cities in the south: deepening social and spatial polarisation in Cape Town. Cities, vol. 24, no. 6, pp. 448-461.

LemBede X.M., 2016. Johannesburg city officials' visions for low-income housing typologies along the Corridors of Freedom. Johannesburg: School of Architecture and Planning, University of the Witwatersrand, [unpublished research report].

LIPIETZ B., 2008. Building a vision for the postapartheid city: What role for participation in Johannesburg's City Development Strategy? International Journal of Urban and Regional Research, vol. 32, no. 1, pp. 135-163.

Lockhat Y., Kotze N., 2017. Rea Vaya in Johannesburg: The reality of an underperforming Bus Rapid Transit System [in:] Proceedings of the 75th Anniversary Congress of the Turkish Geography Society, Ankara, Turkey.

Marals I.E., 2013. Public space/public sphere: An ethnography of Joubert Park, Johannesburg. Johannesburg: University of Johannesburg [Ph.D. Thesis], https://ujdigispace.uj.ac.za/handle/10210/8447 [25 November 2018].

Matjomane K.I., 2012. Cheap rental accommodation in the inner city of Johannesburg, South Africa: The case of Joubert Park. Johannesburg: University of the Witwatersrand [Unpublished Master's Thesis in Development Planning].

MaYson S.S., Charlton S., 2015. Accommodation and tenuous livelihoods in Johannesburg's inner city: the 'rooms' and 'spaces' typologies. Urban Forum, vol. 26, no. 3, pp. 343-372.

McDonald D.A., 2008. World city syndrome: Neoliberalism and inequality in Cape Town. New York: Routledge.

McDonald S., Malys N., Maliene V., 2009. Urban regeneration for sustainable communities: a case study. Technological and Economic Development of Economy, vol. 15, no. 1, pp. 49-59.
Moageng R., Goondiwala Z., 2015. Interview: Operational managers. Rea Vaya Management, Johannesburg (18 September 2015).

NıKŠıč M., TOMINC B., GoRšı̌ N., 2018. Revealing residents' shared values through crowd-sourced photography: Experimental approach in participatory urban regeneration. Urbani Izziv, vol. 29, pp. 29-41.

PIRIE G.H., 2007. Reanimating a comatose goddess: Reconfiguring central Cape Town. Urban Forum, vol. 18, no. 3, pp. 125-151.

PIRIE G.H., 2013. Transport Geography in South Africa. Journal of Transport Geography, vol. 31, pp. 312-314.

POULSEN L., 2010. A room in the city: Strategies for assessing affordable accommodation. Urban Forum, vol. 21, no. 1, pp. 21-36.

RoBINSON J., 2002. City futures: New territories for development studies? [in] J. Robinson (ed.), Development and displacement, Oxford: Oxford University Press, The Open University.

Ross N., Bowen P., Lincoln D., 2010. Sustainable housing for low income communities: Lessons for South Africa and other developing world cases. Construction Management and Economics, vol. 28, no. 5, pp. 443-449.

SChnehage M., 2012. Millions ploughed into reclaiming Joburg's inner city. Business Day, www.moneyweb.co.za [30 June 2012].

South African Cities Network, 2014. Spatial transformation of cities: Conference report: 4-6 March 2014. http://www.sacities.net/wpcontent/uploads/2014/10/spatial_transformation_conference_report_web.pdf [25 October 2018].

Thwaites K., Helleur E., Simkins I.M., 2005. Restorative urban open space: exploring the spatial configuration of human emotional fulfilment in urban open space. Landscape Research, vol. 30, no. 4, pp. 525-547.

THWALA W.D., 2008. Employment creation through public works programmes and projects in South Africa: experiences and potential. Acta Commercii, vol. 8, no. 1, pp. 103-112.

THWALA W.D., 2009. Experiences and challenges of community participation in urban renewal projects: the case of Johannesburg, South Africa. Journal of Construction in Developing Countries, vol. 14, no. 2, pp. 37-54. 
Tissington K., 2013. Minding the Gap: An analysis of supply of and demand for low-income rental accommodation in inner-city Johannesburg. Johannesburg: Socio-economic Rights Institute of South Africa.

TRÓSÁNYY A., 2011. The spatial implications of urban renewal carried out by the ECC programs in Pécs. Hungarian Geography Bulletin, vol. 60 , no. 3, pp. 261-284.

TuRok I., Myknnenk V., 2007. The trajectories of European cities, 1960 - 2005. Cities, vol. 24, no. 3, pp. 165-182.

VisSer G., Kotze N., 2008. The state and newbuild gentrification in central Cape Town, South Africa. Urban Studies, vol. 45, no. 12, pp. 2565-2593.

Walters J., 2013. Overview of public transport policy development in South Africa. Research in Transport Economics, vol. 39, no. 1, pp. 34-45.

WinkLER T., 2013. Why won't Downtown Johannesburg 'regenerate'? Reassessing Hillbrow as a case example. Urban Forum, vol. 24, no. 3, pp. 309-324.

YounG G.A., 2012. Leading with landscape: A regenerative strategy for Johannesburg's inner city. http://sfc2012.org [22 October 2017].

Zack T., Bertoldi A., Charlton S., Kihato M., Silverman M., 2010. Strategy for addressing blighted medium and high density residential 'bad buildings' in Johannesburg: Working document for discussion. Johannesburg: City of Johannesburg. 